\title{
Implementasi Kebijakan Pengembangan Pariwisata di Pulau Lombok
}

\author{
Usman Munir $^{1}$, Khudzaifah Dimyati ${ }^{2}$, Absori $^{3}$ \\ ${ }^{1}$ Dosen Ilmu Hukum, Universitas Muhammadiyah Surakarta, Jl. A. Yani Mendungan Pabelan, Surakarta, \\ 57162 \\ E-mail: usmanmunir.ummat@gmail.com \\ ${ }^{2}$ Dosen Ilmu Hukum, Universitas Muhammadiyah Surakarta, Jl. A. Yani Mendungan Pabelan, Surakarta, \\ 57162 \\ ${ }^{3}$ Dosen Ilmu Hukum, Universitas Muhammadiyah Surakarta, Jl. A. Yani Mendungan Pabelan, Surakarta, \\ 57162
}

Abstract

Lombok is one of the islands of West Nusa Tenggara province with enormous tourism potential, from nature, beaches and culture. So that if this is developed properly it will bring prosperity to the Lombok people in particular and NTB in general. Tourism development policies have not been widely felt to bring effects to welfare to the community. The purpose of this study is to provide an overview of policies and implementation of tourism development policies on tourism on the island of Lombok. Data was collected by observation and interviews. From these data, then analyzed descriptively qualitatively, the data formed becomes a description that describes a situation or event described. Based on the results of the analysis of tourism development policies in Lombok island, it is inseparable from the four tourism pillars contained in regional regulations, namely tourism, marketing, industry and institutional development. The implementation of the policy has not maximally affected the welfare of the people on the island of Lombok, and has even caused new problems in the lower classes.

Keywords : Tourism Policy; Implementation; Lombok.

\begin{abstract}
Abstrak
Lombok adalah salah satu pulau dari provinsi Nusa Tenggara Barat dengan potensi pariwisata yang sangat besar, dari alam, pantai serta budaya. Sehingga jika hal ini dikembangkan dengan baik akan membawa kesejahteraan bagi masyarakat lombok khususnya dan NTB pada umumnya. Kebijakan pengembangan pariwisata belum banyak dirasakan membawa efek kesejahteraan kepada masyarakat. Tujuan penelitian ini adalah untuk memberikan gambaran kebijakan serta implementasi dari kebijakan kepariwisataan pengembangan pariwisata di Pulau Lombok. Data dikumpulkan dengan observasi dan wawancara. Dari data tersebut kemudian dianalisis secara deskriptif kualitatif, data yang terbentuk menjadi deskripsi yang menggambarkan suatu situasi atau peristiwa yang dijelaskan. Berdasarkan hasil analisis kebijakan pengembangan pariwisata dipulau lombok tidak terlepas dari empat pilar pariwisata yang termuat dalam peraturan daerah yakni pengembangan pariwisata, pemasaran, industri dan kelembagaannya. Implementasi dari kebijakan tersebut belum secara maksimal memberikan efek peningkatan kesejahteraan bagi masyarakat di Pulau Lombok, bahkan menimbulkan persoalan-persoalan baru dimasyarakat bawah.

Kata Kunci : Kebijakan Pariwisata, Implementasi, Lombok.
\end{abstract}

\section{A. PENDAHULUAN}

Indonesia sebagai negara kepulauan terbesar di dunia, memiliki sumber daya alam yang sangat besar yang dapat dijadikan potensi pariwisata guna dikelola untuk sebagai sumber devisa negara. Pariwisata dapat juga diandalkan untuk meningkatkan kesejahteraan masyarakat dan pembangunan nasional. ${ }^{1}$ Pentingnya peranan pariwisata dalam pembangunan ekonomi diberbagai negara sudah tidak diragukan lagi. Banyak negara sejak beberapa tahun terakhir menggarap pariwisata dengan serius dan menjadikan pariwisata menjadi sektor unggulan didalam perolehan devisa, terciptanya lapangan kerja maupun pengentasan kemiskinan. ${ }^{2}$

Pariwisata merupakan salah satu penghasil devisa non migas terbesar di Indonesia. ${ }^{3}$ Diakui bahwa sumbangan sektor pariwisata terhadap perolehan devisa dan menciptakan lapangan kerja secara makro cukup signifikan. Laporan berbagai kajian ahli menyimpulkan bahwa sumbangan pariwisata yang secara signifikan pada perkembangan ekonomi suatu negara atau daerah tampak dalam bentuk perluasan peluang kerja,

\footnotetext{
${ }^{1}$ I Gede Pitana \& Putu G Gayatri, Sosiologi Pariwisata, Yogyakarta, Andi, 2005. hlm 137

${ }^{2}$ I Gde Pitana \& Ketut Surya Diarta, Pengantar Ilmu Pariwisata, Yogyakarta, Andi, 2009, hlm 2

${ }^{3}$ Sukarno Wibisono, Pariwisata sebagai disiplin ilmu yang mandiri, Jurnal Ilmiah Pariwisata, hlm 6
} 
Website : http://yustisia.unmermadiun.ac.id/index.php/yustisia

meningkatkan pendapatan (devisa) dan pemerataan pembangunan spasial. ${ }^{4}$ Selama beberapa dekade terakhir ini, pariwisata telah menjadi beberapa sumber utama pendapatan bagi banyak negara, khususnya bagi negara-negara didunia Ketiga. International Monetary Fund (IMF) dan World Economic Forum (WEF) memprediksikan kenaikan aktifitas ekonomi hanya sebesar $0,2 \%$ pada tahun $2015 .^{5}$

Pulau Lombok yang merupakan bagian dari Provinsi Nusa Tenggara Barat memiliki potensi yang sangat besar dalam hal potensi wisata, karena memiliki berbagai potensi wisata, baik wisata alam, buatan maupun wisata pantai. Potensi yang besar ini dijadikan peluang oleh pemerintah daerah guna dikelola dan dijadikan sebagai sumber meningkatkan kesejahteraan masyarakat serta dimungkinkan oleh undang-undang otonomi daerah untuk mengelola potensi daerah sendiri. Selain itu Pulau Bali dan Lombok oleh pemerintah pusat ditetapakn menjadi pintu gerbang pariwisata nasional dalam MP3EI Kridor V (Masterplan Percepatan dan Perluasan Pembangunan Ekonomi Indonesia). ${ }^{6}$ Dengan demikian kebijakan untuk mengelola potensi pariwisata lombok diharapkan akan mampu menyumbang pendapatan daerah yang berdampak pada kesejahteraan bagi masyarakat. Kebijakan pengembangan pariwisata dipulau Lombok melalui Peraturan Daerah Nomor 7 Tahun 2013 Tentang Rencana Induk Pengembangan Pariwisata Daerah, dirasakan secara empiris belum dirasakan manfaat yang besar bagi peningkatan kesejahteraan masyarakat bahkan yang ada semakin meningkatnya kesenjangan sosial.

Dari uraian diatas, mencoba untuk merumusakan tujuan dan masalah terkait kebijakan pariwisata di Pulau Lombok. Adapun tujuan dan masalah dari penelitian ini adalah mengidentifikasi dan menganalisis serta mengkaji kebijakan dan implementasi kebijakan kepariwisataan di pulau lombok dengan memberikan diskripsi kebijakan dan melihat secara empiris implementasi dari kebijakan yang ada.

\section{B. METODE PENELITIAN}

Dalam penelitian ini paradigma yang digunakan adalah paradigma non doctrinal (socio legal research) untuk menemukan teori-teori tentang proses terjadinya dan bekerjanya hukum dalam masyarakat, Suatu studi yang meninjau hukum sebagai fakta sosial yang bisa tersimak di alam pengalaman sebagai pola perilaku dalam wujud pranata sosial atau institusi sosial, kajian hukum yang mengkonsepkan dan menteorikan hukum sebagai fakta sosial yang positif dan empiris. ${ }^{7}$

Tipe kajian dalam penelitian ini adalah bersifat deskriptif, bermaksud memberikan gambaran tentang berbagai hal yang berkaitan dengan masalah dalam penelitian. Metode pengumpulan data adalah observasi, wawancara dan studi dokumen. Pendekatan yang akan digunakan adalah Pendekatan kasus (Case approach), Pendekatan perundang-undangan (Statute Approach). Adapun tujuan penelitian ini adalah memberikan gambaran kebijakan dan Implementasi pengembangan pariwisata di pulau Lombok.

\section{KAJIAN PUSTAKA}

\section{Pengertian Kebijakan}

Pembangunan wilayah sangat penting, terutama sekali dikaitkan dengan era desentralisasi yang melahirkan kompetensi baru bagi pemerintah daerah yang guna mengoptimalkan potensi, asset lokal dan modal sosial setempat untuk memajukan kesejahteraan masyarakat.8 Setiap sistem politik membuat kebijakan publik. Bahkan dapat dikatakan bahwa produk utama dari sistem dan proses politik adalah kebijakan publik.9 Setiap kebijakan dilaksanakan dengan mengerahkan sumber daya publik. Jadi kebijakan publik selalu bersangkut paut atau berimplikasi pada gangguan sumberdaya publik- baik implikasi possitif/aktif (dikerahkannya sumberdaya untuk suatu isu) maupun negatif/pasif (tidak dikerahkannya sumberdaya untuk suatu isu, agar tersedia sumberdaya untuk isu yang lain). ${ }^{10}$ Beberapa difinisi kebijakan diantaranya sebagai berikut ${ }^{11}$;

\footnotetext{
${ }^{4}$ Junianton Damanik, Pariwisata Indonesia antara peluang dan Tantangan, Pustaka Pelajar, Jogyakarta, 2013, hlm 4

5 International Monetary Fund, "World Economic Outlook (WEO) update: is the Tide Rising?", 2014, http://www/imf.org/external/pubs/ft/weo/2014/01/world Economic and Financial Surveys Global activity strengthened during the second half of 2013, as anticipated in the October 2013 World Economic Outlook (WEO). (Diunduh pada 5/02/2014)

${ }^{6}$ Riparda 2015-2019 NTB, hlm 12

7 Soetandyo Wignjosoebroto, Hukum, Paradigma, Metode dan Dinamika Masalahnya, Elsam dan Huma, Jakarta, 2002, hlm. 183.
}

8 Isharyanto, Hukum Kebijakan Ekonomi Publik, Thafa Media,Yogyakarta, 2016, hlm 215

9 Samodra Wibawa, Politik Perumusan Kebijakan Publik,Graha Ilmu,Yogyakarta 2011, hlm 1

10 Ibid, hlm 2

11 Ibid, hlm 2 
Website : http://yustisia.unmermadiun.ac.id/index.php/yustisia

1.Carl Friedrich, mendifinisikan kebijakan adalah arah tindakan yang diusulkan oleh seseorang, kelompok atau pemerintah dalam suatu lingkungan tertentu, yang memberikan hambatan-hambatan atau kesempatan-kesempatan dalam rangka mencapai suatu tujuan atau merealisasikan suatu sasaran atau maksud tertentu.

2.Richard Rose, berpendapat kebijakan adalah serangkaian kegiatan yang sedikit banyak berhubungan beserta konsekuensi-konsekuensinya bagi mereka yang bersangkutan, bukan keputusan yang berdiri sendiri-sendiri.

3.Thomas R. Dye menyatakan bahwa kebijakan adalah apapun yang dipilih pemerintah untuk dilakukan atau tidak dilakukan.

4.James E. Anderson berpendapat, bahwa kebijakan adalah arah tindakan yang mempunyai maksud, yang ditetapkan oleh seseorang atau beberapa actor guna mengatasi suatu masalah.

Kebijakan (policy) adalah sebuah instrument pemerintahan, bukan saja dalam arti Government yang hanya menyangkut aparatur Negara, melainkan pula governance yang menyentuh pengelolahan sumberdaya publik. Kebijakan pada intinya merupakan keputusan-keputusan atau pilihan-pilihan tindakan yang secara langsung mengatur pengelolahan dan pendistribusian sumberdaya alam, finansial dan manusia demi kepentingan publik. ${ }^{12}$

Analisis kebijakan publik bisa didifinisikan sebagai sebagai penentu alternatif terbaik dari kebijakan publik yang mampu memberikan jalan keluar dari berbagai macam alternatif kebijakan publik dan pemerintahan, dan yang akan paling banyak mencapai seperangkat tujuan di dalam hal hubungan antara kebijakan dan tujuan. Difinisi ini menentukan lima unsur pokok evaluasi kebijakan; ${ }^{13}$ pertama, Tujuan (goals), termasuk kendala normatif dan pertimbangan relative untuk mencapai tujuan (goals). Kedua, Kebijakan, program, proyek, keputusan, pilihan, sarana atau alternatif lain yang tersedia untuk mencapai tujuan. Ketiga, Hubungan antara kebijakan dan tujuan, termasuk hubungan yang terbentuk oleh intuisi, kewenangan, statistik, pengamatan, deduksi, perkiraan atau sarana lain. Keempat, penarikan kesimpulan tentative sebagai kebijakan atau kombinasi kebijakan yang mana yang paling baik untuk diadopsi dalam hal tujuan, kebijakan dan hubungan. Kelima, Menentukan apa yang akan dilakukan untuk memetakan alternatif kebijakan.

Metodelogi analisis kebijakan publik diambil dari dan memadukan elemen-elemen dari berbagai disiplin: ilmu politik, sosiologi, psikologi, ekonomi, filsafat. Analisis kebijakan sebagaian bersifat deskriptif, yang mencari pengetahuan tentang sebab dan akibat kebijakan-kebijakan publik. Namun analisis kebijakan juga bersifat normative, tujuan lainnya adalah menciptakan dan melakukan kritik terhadap klaim pengetahuan tentang nilai kebijakan publik untuk generasi masa lalu, masa kini, dan masa mendatang. ${ }^{14}$

Dari beberapa difinisi kebijakan diatas maka penulis mencoba merumuskan difinisi kebijakan sebagai berikut; tindakan pemerintah baik tertulis maupun tidak tertulis guna mencapai tujuan tertentu dan mengatasi masalah tertentu. Bentuk kebijakan tertulis bisa berupa peraturan pemerintah, perda, pergub, sampai dengan perdes, sedangkan bentuk yang tidak tertulis bisa dalam bentuk awik-awik desa, dan nilai-nilai yang yang hidup dan ditaati.

\section{Pengertian Pariwisata}

Definisi Pariwisata dapat dilihat dalam Undang-Undang Kepariwisataan baik yang lama maupun yang baru, dalam Undang-Undang Kepariwisataan yang baru yakni Undang Undang Nomor 10 Tahun 2009 dalam Pasal 1 ayat (3) diuraikan difinisi Pariwisata adalah berbagai macam kegiatan wisata dan didukung berbagai fasilitas serta layanan yang disediakan oleh masyaraka, pengusaha, Pemerintah dan Pemerintah Daerah.

Sedangkan dalam Undang Undang Nomor 9 Tahun 1990 tentang Kepariwisataan (Undang Undang Kepariwisataan Lama) dalam Pasal 1 ayat (3) dapat dilihat definisi sebagai berikut; Pariwisata adalah kegiatan yang bertujuan menyelenggarakan usaha jasa pariwisata atau menyediakan atau mengusahakan objek dan daya tarik wisata, usaha sarana pariwisata dan usaha lain yang terkait usaha bidang tersebut.

Menurut Bernecker, 1965; The first definition may have been produced in 1910 by the Austrian economist Herman von Schullern zu Schrattenhofe ; according to him, tourism is "the set of all the phenomena, especially economic ones,produced by the arrival, stay and departure of travelers in a certain commune, province or state and which, as aconsequence, are directly linked to them" ${ }^{15}$

\footnotetext{
${ }^{12}$ Edi Suharto, Kebijakan Sosial Sebagai Kebijakan Publik, Alfabeta,Bandung, 2008, hlm 3

${ }^{13}$ Hessel Nogi S. Tangkilisan, Evaluasi Kebijakan Publik, Penjelasan, Analisis \&Transformasi Pikiran Nagel, Balaiirung \& Co, Yogyakarta, 2003, hlm 2-3

${ }^{14}$ William N Dunn, Pengantar Analisis Kebijakan Publik, Gadjah Mada Universty, 2003, hlm 3

${ }^{15}$ Licínio Cunha, The Definition and Scope of Tourism: a Necessary Inquiry, Universidade Lusófona de Humanidades e Tecnologias. hlm 100
} 
Website : http://yustisia.unmermadiun.ac.id/index.php/yustisia

Definisi lainya tentang pariwisata dalam Wikipedia adalah Tourism is the act of travel for predominantly recreational or leisure purposes, and also refer to the provision of services in support of this act. ${ }^{16}$ Ada juga definisi pariwisata menurut The British Tourist Authority adalah " A stay of one on more nights away from home for holidays, visit to friend or relatives, business conferences or any otherpurpuse except such things as boarding education or semi permanent employment". ${ }^{17}$

Sedangkan difinisi pariwisata secara umum menurut World Tourism Organization atau Organization Mondiale du Tourism atau UNWTO adalah " An activicy where in the tourist or people who, "travel to and stay in places out side their usual environment for not more than one consecutive year for leisure, business and other purpuses not related to the exercise of an activity rumenerated from within the place visited". ${ }^{18}$

Beberapa difinisi pariwisata lainnya dapat diuraiakan sebagai berikut :

1.Menurut Syafiie pariwisata adalah suguhan kunjungan yang bertata karma dan berbudi sedangkan Suwantoro menyatakan pariwisata berhubungan dengan pengertian perjalanan wisata, yaitu suatu perubahan tempat tinggal sementara seseorang di luar tempat tinggalnya karena suatu alasan, misalnya untuk mendapatkan kenikmatan dan memenuhi hasrat ingin mengetahui sesuatu sehingga mendorong untuk bepergian dengan motif berbagai kepentingan, seperti ekonomi, sosial, kebudayaan, agama, kesehatan dan kepentingan lain seperti ingin tahu, menambah pengalaman atau untuk meneliti. ${ }^{19}$

2.Methiesson \& Waill, pariwisata adalah pergerakan manusia yang bersifat sementara ke tujuan-tujuan wisata diluar tempat kerja dan tempat tinggal sehari-hari dimana aktivitasnya dilaksanakan selama tinggal di tempat tujuan wisata dan untuk disediakan fasilitas-fasilitas yang memenuhi kebutuhan mereka. ${ }^{20}$

3.Kodhyat (1998) pariwisata adalah perjalanan dari suatu tempat ketempat lain, bersifat sementara, dilakukan perorangan atau kelompok, sebagai usaha mencari keseimbangan atau keserasian dan kebahagian dengan lingkungan dalam dimensi sosial, budaya, alam dan ilmu.

4.Gamal (2002), pariwisata didefinisikan sebagai bentuk. suatu proses kepergian sementara dari seorang, lebih menuju ketempat lain diluar tempat tinggalnya.

5.Burkart dan Medlik (1987) menjelaskan pariwisata sebagai suatu trasformasi orang untuk sementara dan dalam waktu jangka pendek ketujuantujuan di luar tempat di mana mereka biasanya hidup dan bekerja, dan kegiatankegiatan mereka selama tinggal di tempat-tempat tujuan itu.

Beberapa difinisi diatas penulis melihat difinisi yang diuraikan Methiesson \& Waill lebih sesuai yaitu pergerakan manusia yang bersifat sementara ke tujuan-tujuan wisata diluar tempat kerja dan tempat tinggal sehari-hari dimana aktivitasnya dilaksanakan selama tinggal di tempat tujuan wisata dan untuk disediakan fasilitas-fasilitas yang memenuhi kebutuhan mereka dan dari difinisi diatas maka penulis mencoba menguraikan apa yang menjadi unsur-unsur dari pariwisata yakni kegiatan yang bersifat sementara dilakukan dalam waktu singkat diluar tempat kerja, dengan tujuan wisata dan tersedianya fasilitas guna memenuhi kebutuhannya selama kegiatan berlangsung.

\section{Sejarah Kepariwisataan Indonesia}

Kegiatan Pariwisata diIndonesia sudah dilakukan sejak zaman dulu atau lebih tepatnya ketika masa kerajaan. Para pejabat kerajaan diketahui sangat gemar berpetualang walaupun daerah yang dikunjungi terbatas karena terbatasnya sarana dan prasanan saat itu. Sejarah pariwisata di Indonesia sendiri dibagi menjadi tiga periode. Periode masa penjajahan Belanda, periode masa penjajahan jepang dan periode masa setelah kemerdekaan Indonesia merdeka.

Periode masa penjajahan Belanda, pariwisata zaman ini dimulai sekitar tahun 1910 setelah pemerintah belanda mendirikan sejenis kantor travel yang bernama VTV (Vereeneging Toesristen Verker). Seiring dengan bertambahnya volume perdagangan antara benua Eropa dan Asia maka semakin ramai pula lalu lintas kunjungan untuk masing-masing daerah yang memicu munculnya berbagai agen-agen dibidang pariwisata dan juga sarana pendukungnya seperti hotel. Daerah yang paling besar terkena imbas kegiatan pariwisata saat itu adalah Jakarta, Medan, Bandung, Surabaya dan Denpasar. Pada masa penjajahan belanda kegiatan pariwisata dilakukan hanya oleh kulit putih saja.

\footnotetext{
${ }^{16}$ Wikipedia, at http: wiki.Tourism.

${ }^{17}$ Violetta Simatupang, Pengaturan Hukum Kepariwisataan Indonesia, Alumni Bandung, 2016, HIm 24

${ }^{18}$ www. worldtourim organization.

${ }^{19}$ Bungaran Antonius Simanjuntak (at.al), Sejarah Pariwisata, Menuju Perkembangan Pariwisata Indonesia, Buku Obor, Jakarta, 2017, Hlm 2

${ }^{20}$ Ahmad Nawawi, Partisipasi Masyarakat dalam Pengelolaan Wisata Pantai Depok di Desa Parangtritis, Jurnal Nasional Pariwisata (UGM), Volume 5, Nomor 2, Agustus 2013, hlm 105
} 
Website : http://yustisia.unmermadiun.ac.id/index.php/yustisia

Periode masa Penajajahan Jepang, Pariwisata pada masa ini bisa dibilang tengah terpuruk karena adanya perang dunia II dan pendudukan Jepang di Indonesia. Orang-orang terutama dari kulit putih tidak antusias dan berkesempatan melakukan perjalanan ke Indonesia karena situasi yang kacau, sarana dan prasarana seperti jembatan, jalan, dan bangunan banyak yang rusak akibat perang dan objek wisata juga menjadi terbengkalai. Sementara itu bom Hiroshima dan Nagasaki juga berimbas pada terpuruknya perekonomian Indonesia.

Periode setelah kemerdekaan Indonesia, pada masa ini pariwisata tumbuh kembali dengan tujuan meningkatkan perekonomian Indonesia. Ditandai ketika Hotel Indonesia diresmikan pada tahun 1962. Pada awal tahun 1960-an mulai divisualisasikan dengan didirikannya simbol-simbol monumentalisme Soekarno di Jakarta. Pada era 1970-an mulai muncul hotel-hotel dan pasilitas pariwisata lainnya di Bali. ${ }^{21}$ Dimulai sejak era tersebut pemerintah memegang peranan penting dalam perkembangan Industri ini termasuk penyusunan kebijakan-kebijakan dan peraturan-peraturan yang bertujuan untuk menstimulasi kunjungan wisatawan mancanegara ke Indonesia. Pembangunan pariwisata memiliki peran signifikan dalam aspek ekonomi, sosial dan lingkungan, dalam aspek ekonomi sektor pariwisata memberikan kontribusi devisa dari kunjungan para wisatawan manca Negara. ${ }^{22}$

Pada masa setelah kemerdekaan yang juga dikenal dengan masa Orde Lama, pembangunan ekonomi berdasarkan pada Pembangunan Nasional Semesta Delapan Tahun 1961 - 1969 yang ditetapkan melalui Ketetapan MPRS Republik Indonesia No. II/MPRS/1960 Tentang Garis-Garis Besar Pola Pembangunan Nasional Semesta Berencana Tahapan Pertama 1061- 1969. Pada masa itu, pembangunan pariwisata belum menjadi perhatian pemerintah. Fokus pemerintah pada pada saat itu masih pada pembangunan dan pembenahan perekonomian nasional sehingga mampu berdiri sendiri. Pembangunan diprioritaskan pada bidang pertanian dan meletakkan dasar-dasar bagi industrialisasi terutama industri dasar dan industri berat.

Memasuki era Orde Baru kondisi sosial, ekonomi dan politik secara bertahap mulai tertata. Pembangunan nasional pada masa itu mengacu pada Garis-garis Besar Haluan Negara (GBHN) yang ditetapkan oleh Majelis Permusyawaratan Rakyat (MPR). GBHN pada dasarnya memuat Pola Umum Pembangunan Jangka Panjang yang memuat ketentuan-ketentuan mengenai pelaksanaan pembangunan Nasional untuk masa 25 tahun, yaitu selama terlaksananya Pembangunan Lima Tahun (PELITA) I sampai dengan V. ${ }^{23}$

Di masa Orde Baru pembangunan pariwisata mulai mendapat perhatian pemerintah yang ditandai dengan dituangkannya kebijakan pembangunan kepariwisatan di dalam Pembangunan Jangka Panjang 25 tahun pertama yang dimulai tahun 1967/68 dan berakhir pada tahun 1998/99. Pembangungan Jangka Panjang tersebut kemudian dijabarkan ke dalam rencana lima tahunan yang dikenal dengan Rencana Pembangunan Lima Tahun (Repelita Pertama - Repelita Keenam).

\section{HASIL PENELITIAN DAN PEMBAHASAN}

\section{Kebijakan Pariwisata di Pulau Lombok}

Pembangunan wilayah sangat penting, terutama sekali dikaitkan dengan era desentralisasi yang melahirkan kompetensi baru bagi pemerintah daerah yang guna mengoptimalkan potensi, asset lokal dan modal sosial setempat untuk memajukan kesejahteraan masyarakat. ${ }^{24}$ Dalam pengembangan kepariwisataan di Pulau Lombok, pemerintah daerah Provinsi Nusa Tenggara Barat memilki Visi yakni "Lombok Sebagai Destinasi Wisata Berbasis Alam dan Budaya, yang Berdaya Saing dan Berkelanjutan." 25 Tujuan dan strategi untuk pengembangan yang berkelanjutan menitik beratkan pada empat pilar utama kepariwisataan yang terdapat dalam RIPPARDA NTB 2013-2028: Destinasi, Pemasaran, Industri, dan Kelembagaan dan SDM. Tujuan utama dari Rencana Induk Pariwisata Berkelanjutan (Sustainable Tourism Master Plan - STMP) yaitu sebagai berikut:

1.Untuk membangun dan menuangkan sasaran bersama dan arahan untuk sektor industri, masyarakat dan pemerintah;

2.Untuk mengembangkan strategi dalam mencapai sasaran bersama dan untuk menentukan peran dari masing-masing institusi;

3.Untuk menyediakan dasar dalam menentukan prioritas untuk penerapan yang strategis.

4.Untuk menyediakan kerangka kerja yang disetujui dalam pengembangan pariwisata Lombok yang berkelanjutan untuk jangka panjang.

Tujuan dan Strategi 4 Pilar Pariwisata Pulau Lombok

\section{A. Pengembangan Destinasi Pariwisata di Pulau Lombok}

\footnotetext{
${ }^{21}$ Violatta Simatupang, Op. Cit, hlm 116

${ }^{22}$ Iwan Nugroho, Ekowisata dan Pembangunan Berkelanjutan, Pustaka Pelajar, Yogyakarta, 2011, hlm 1

${ }^{23} \mathrm{GBHN}$, Ginandjar Kartasasmita

${ }^{24}$ Isharyanto, Hukum Kebijakan Ekonomi Publik, Thafa Media, Yogyakarta, 2016, hlm 215

${ }^{25}$ Ripparda, NTB 2013-2028
} 
Website : http://yustisia.unmermadiun.ac.id/index.php/yustisia

\begin{tabular}{|c|c|}
\hline $\begin{array}{l}\text { Tujuan 1: } \\
\text { Partisipasi masyarakat lokal dalam } \\
\text { membangun destinasi }\end{array}$ & $\begin{array}{l}\text { 1. Mengikut sertakan tokoh masyarakat serta para pendidik } \\
\text { formal dan non formal dalam proses promosi } \\
\text { kepariwisataan kepada masyarakat dan pemberdayaan } \\
\text { masyarakat di destinasi pariwisata. } \\
\text { 2. Meningkatkan pemberdayaan masyarakat dan } \\
\text { memaksimalkan keuntungan ekonomi bagi masyarakat. }\end{array}$ \\
\hline $\begin{array}{l}\text { Tujuan 2: } \\
\text { Membangun destinasi pariwisata yang } \\
\text { unik, bersih, otentik dan } \\
\text { berkelanjutan. }\end{array}$ & $\begin{array}{l}\text { 1. Meneliti dampak lingkungan secara komprehensif. } \\
\text { 2. Membuat dan memberlakukan awig-awig di kawasan } \\
\text { pariwisata. } \\
\text { 3. Membangun sarana dan prasarana pariwisata skala kecil } \\
\text { yang dikelola oleh masyarakat setempat. } \\
\text { 4. Mengidentifikasi potensi pengembangan wisata maritim. } \\
\text { 5. Mengembangkan langkah-langkah adaptasi terhadap } \\
\text { perubahan iklim. }\end{array}$ \\
\hline $\begin{array}{l}\text { Tujuan 3: } \\
\text { Membangun destinasi pariwisata yang } \\
\text { aman dan nyaman. }\end{array}$ & $\begin{array}{l}\text { 1. Membentuk pramswakarsa pariwisata. } \\
\text { 2. Mencegah praktik seks komersial atau segala macam } \\
\text { bentuk eksploitasi dan pelecehan terhadap siapa pun, } \\
\text { khususnya anak-anak, remaja, wanita, dan minoritas. }\end{array}$ \\
\hline \multicolumn{2}{|c|}{ B. Pemasaran pariwisata di Pulau Lombok } \\
\hline $\begin{array}{l}\text { Tujuan 4: } \\
\text { Meningkatkan kualitas kunjungan dan } \\
\text { kepuasan wisatawan. }\end{array}$ & $\begin{array}{l}\text { 1. Pemasaran terpadu antara pemerintah dan swasta dengan } \\
\text { strategi yang menggunakan pendekatan terstandarisasi. } \\
\text { 2. Menerapkan strategi pemasaran yang disesuaikan untuk } \\
\text { mengakomodir kepentingan dari pasar pariwisata yang } \\
\text { paling menjanjikan. }\end{array}$ \\
\hline \multicolumn{2}{|c|}{ C. Industri Pariwisata di Pulau Lombok } \\
\hline $\begin{array}{l}\text { Tujuan 5: } \\
\text { Memiliki institusi pariwisata yang } \\
\text { didukung oleh Sumber Daya Manusia } \\
\text { pekerja yang professional. }\end{array}$ & $\begin{array}{l}\text { 1. Pemberian kursus, pelatihan, dan sertifikasi tenaga kerja } \\
\text { khususnya pemandu wisata, anggota pokdarwis, tenaga } \\
\text { kerja pariwisata dan siswa SMK pariwisata. }\end{array}$ \\
\hline $\begin{array}{l}\text { Tujuan 6: } \\
\text { Memiliki institusi pariwisata yang } \\
\text { didukung oleh publik }\end{array}$ & $\begin{array}{l}\text { 2. Meningkatkan partisipasi publik dalam perencanaan } \\
\text { destinasi dan pengembalian keputusan dalam } \\
\text { pengembangan destinasi pariwisata berkelanjutan dengan } \\
\text { melibatkan pemangku kepentingan pariwisata lainnya dan } \\
\text { bisnis pariwisata (hotel \& tour operator). }\end{array}$ \\
\hline \multicolumn{2}{|c|}{ D. Kelembagaan pariwisata di Pulau Lombok } \\
\hline $\begin{array}{l}\text { Tujuan 7: } \\
\text { Menciptakan lingkungan usaha yang } \\
\text { kondusif agar industri pariwisata dapat } \\
\text { menciptakan produk/jasa yang kreatif } \\
\text { dan inovatif. }\end{array}$ & $\begin{array}{l}\text { 1. Mengembangkan produk lokal yang berkelanjutan dan } \\
\text { perdagangan yang adil (fair trade). } \\
\text { 2. Memberikan akses keuangan dan peningkatan kapasitas } \\
\text { Usaha Mikro, Kecil dan Menengah (UMKM). } \\
\text { 3. Menghubungkan kelompok produk lokal dengan bisnis } \\
\text { pariwisata. } \\
\text { 4. Menumbuhkan jiwa kewirausahaan pariwisata di kalangan } \\
\text { masyarakat tujuan wisata. }\end{array}$ \\
\hline 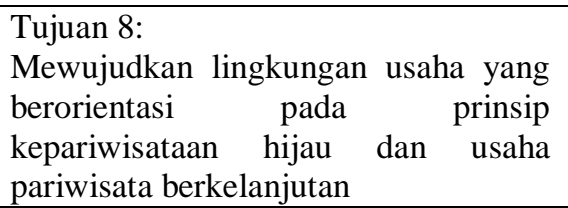 & $\begin{array}{l}\text { 1. Memberikan insentif dan mendirikan lembaga sertifikasi } \\
\text { untuk pengusaha wisata lokal. }\end{array}$ \\
\hline
\end{tabular}

Pemerintah daerah dalam pengembangan destinasi di pulau Lombok berpedoman pada empat pilar pariwisata diatas, bebera upaya yang dilakukan pemerintah daerah dalam mengembangkan destinasi pariwasata antara lain yakni, Pembangunan Kawasan Ekonomi Khusus (KEK) Mandalika telah ditetapkan melalui PP Nomor 52 Tahun 2014 pada tanggal 30 Juni 2014. Pemeritah pusat melalui kementerian pariwisata telah menentapkan 10 destinasi prioritas yakni; Mandalika, Candi Borobudur, Labuan Bajo, Danau Toba, Wakatobi, Bromo-Tengger-Semeru, Tanjung Lesung, Marotai, dan Tanjung Kelayang. Persyaratan bagi operasional KEK telah disiapkan seperti Lahan, administrator, pelimpahan kewenangan, perangkat pendukung dan infrastruktur 
Website : http://yustisia.unmermadiun.ac.id/index.php/yustisia

dalam kawasan. Dan seluruh kegiatan pengembangan KEK dari perencaan sampai dengan pembangunan sepeluruh dikerjakan oleh PT.ITDC (Indonesia Tourism Development Corporation). ${ }^{26}$

KEK Mandalika memiliki kawasan seluas 1034 Hektar (ha), pembangunan fisik yang sedang berlangsung yakni pembangunan Hotel Pullman dan Hotel Clubmen, Masjid dengan kapasitas besar dimana pembangunanya sudah mencapai 90 persen, serta jalan sepanjang $7 \mathrm{~km}$. sedangkan rencana dukungan dari pemerintah daerah adalah jaringan jalan, irigasi dan Air bersih. Berbagai kemudahan dibuka oleh pemerintah dengan memeberikan fasilatas kemudahan di KEK yang ditetapkan melalui PP Nomor 96 Tahun 2015 tentang Fasilitas dan Kemudahan di KEK, serta Perpres Nomor 3 Tahun 2013 Tentang Proyek Strategis Nasional. Fasilitas dan kemudahan diatas antaranya PPh Badan, Pembebasan PPh Pasal 22 Impor, Fasilitas PPN dan PPnBM, Fasilitas Bea Masuk dan Cukai, Fasilitas Kegiatan Utama Pariwisata, Fasilitas Lalu Lintas Barang, Fasilitas Ketenagakerjaan, Fasilitas Keimigrasian, Fasilitas Pertanahan, Fasilitas Perizinan dan Non Perizinan.

Kelebihan pantai sekitar KEK Mandalika memiliki morfologi pantai panjang yakni 87 km, dan masingmasing memiliki teluk dan masing-masing teluk memiliki keunikan misalkan teluk Tunak surfing, diharapkan KEK Mandalika akan menjadi pemicu pengembangan wilayah sekitar, jika KEK Mandalika berkembang maka akan membangkitkan juga penyangga-penyangga ITDC lainnya. ${ }^{27}$ Selain pengembangan destinasi pariwsata KEK, pemerintah juga mengembangkan destinasi lainnya. Di kabupaten Lombok Barat daerah kawasan wisata Senggigi dengan wisata pantainnya, kabupaten Lombok Utara dengan tiga pesona Gili menjadi daya tarik wisata pantai selain itu wisata buatan sebagai pendukung mulai bermunculan. Begitu juga destinasi dikawasan kabupaten Lombok Timur yang menyediakan wisata alam dan religi.

Pesona Lombok sebagai daerah pariwisata mendapat penghargaan Internasional, dua penghargaan diraih dalam ajang World Halal Travel Award (WHTA) 2015. Dua penghargaan itu antara lain pertama World Best Halal Tourism Destination (Destinasi Wisata Halal Terbaik Dunia) dan World Best Halal Honeymoon Destination (Destinasi Bulan Madu Halal Terbaik Dunia). Sebagai salah satu destinasi prioritas nasional dalam pembangunan wisata halal, di Pulau Lombok ada kawasan Mandalika dan Sekitarnya dijadikan sebagai salah satu destinasi wisata halal dengan visi World's Best Halal Tourism and Cruise Destination dengan tujuan untuk menjadikan kawasan tersebut sebagai salah satu pilihan tempat wisata halal terbaik dunia bagi semua wisatawan $^{28}$, khususnya wisatawan muslim dan mampu menjadi pintu masuk dalam menarik 1 juta kunjungan wisatawan mancanegara pada tahun 2019, dengan target pasar wisatawan mancanegara yaitu: Malaysia, Singapura, Brunei, Thailand, Taiwan, Jepang, Negara-Negara di Kawasan Timur Tengah, Eropa, Tiongkok, Amerika Serikat. Serta Daya Tarik Wisata (DTW) meliputi: Danau Segara Anak, Puncak Gunung Rinjani, Sumber Air Panas, Lava, Hutan, Air Terjun, Flora dan Fauna, Tenun, Peresean, Gendang Beleq, NgayuNgayu. ${ }^{29}$

Dalam meningkatkan kualitas kunjungan dan kepuasan wisatawan pemerintah daerah melakukan berbagai promosi diantaranya meluncurkan program Visit Sumbawa Lombok, Program Visit Sumbawa Lombok 2012 diluncurkan oleh Presiden Susilo Bambang Yudhoyono pada tanggal 6 Juli 2009 dengan target 1 juta wisatawan, dan dilanjutkan dengan peluncuran program Visit Lombok Sumbawa 2015 dengan target 2 juta wisatawan. Program Visit Lombok Sumbawa bertujuan meningkatkan kunjungan wisatawan ke Pulau Lombok dan Sumbawa. Pada tahun 2015 lalu program Visit Lombok Sumbawa Mengangkat Tema "Tambora Menyapa Dunia" program ini sukses menaikan angka kunjungan wisatawan pada akhir tahun 2015. Dari berbagai kegiatan promosi pariwisata yang telah dilakukan sebelumnya, terdapat beberapa hal yang masih dikeluhkan wisatawan mancanegara maupun wisata lokal. Aspek tersebut adalah kurangnya pengenalan tujuan wisata, kurangnya pameran serta informasi tujuan wisata di internet. Aspek ini berdasarkan hasil survey referensi wisatawan terhadap pengembangan pariwisata NTB. ${ }^{30}$

\footnotetext{
${ }^{26}$ Wawanca Bapak Zulfa, Kasi Destinasi Dinas Pariwisata Kabupaten Lombok Tengah 4 Agustus 2017

${ }^{27}$ Wawanca Bapak Zulfa, Kasi Destinasi Dinas Pariwisata Kabupaten Lombok Tengah 4 Agustus 2017

${ }^{28}$ Dengan dua penghargaan sekaligus yang diraih pulau lombok oleh pemerintah daerah disambut dengan mengarahkan kebijakan pada pengembangan pariwisata halal yang barengi dengan dikeluarkannya Peraturan Gubernur Nomor 51 Tahun 2015 tentang Wisata Halal, yang dilanjutkan dengan diterbitkannya Peraturan Daerah Nomor 2 tahun 2016 tentang Pariwsata Halal. Dengan terbutnya perda tersebut pemerintah daerah melanjutkan dengan mensertifikasi berbagai produk pendukung kegiatan wisata seperti Hotel, Rumah Makan dan lainnya dengan memberikan sertifikasi halal.

${ }^{29}$ Destinasi Pariwisata Prioritas Mandalika Dan Sekitarnya, dalam: Laporan Pembangunan Destinasi Pariwisata Prioritas 2016-2019, disampaikan oleh: Dadang Rizki Ratman, SH. MPA. Deputi Bidang Pengembangan Destinasi dan Investasi Pariwisata Kementerian Pariwisata, Disampaikan pada: Rapat Koordinasi Nasional Kementerian Pariwisata "Äkselerasi Pembangunan Kepariwisataan Dalam Rangka Pencapaian Target 12 Juta Wisman dan 260 Juta Wisnus 2016", Jakarta, 27 Januari 2016

${ }^{30}$ Pusat Penelitian dan Pengembangan Usaha Mandiri (P3UM), Survey Referensi Wisatawan Terhadapat Pengembangan Pariwisata, Mataram, Universitas Mataram, 2010
} 
Website : http://yustisia.unmermadiun.ac.id/index.php/yustisia

Untuk itu Badan Promosi Pariwisata Daerah Nusa Tenggara Barat yang berfungsi sebagai koordinator promosi pariwisata sebagai mitra daerah dan pusat dalam meningkatkan citra pariwisata Indonesia telah membuat media promosi online secara resmi. Media tersebut berbentuk website beralamat di www.lomboksumbawa.travel. Website ini sengaja dibuat dalam mendukung program pariwisata NTB "Visit Lombok Sumbawa". ${ }^{31}$ Bentuk-bentuk promosi yang dilakukan dalam rangka Visit Lombok Sumbawa adalah; Perilklanan (Advertising), Promosi Penjualan (Sales Promotion), Hubungan Publik (Publik Relation), Penjualan Perseorangan (Personal Selling), Pemasaran Langsung (Direct Marketing), Informasi Mulut ke Mulut (Worth mouth to mouth), Pemasaran Internet (Internet Marketing). ${ }^{32}$

Pemerintah provinsi Nusa Tenggara Barat melalui dinas pariwisata menetapkan Frendly Lombok dan Pesona Sumbawa menjadi Branding Pesona Indonesia, ini merupakan program kementerian pariwisata Republik Indonesia untuk memperkenalkan keberagaman dan keindahan pariwisata Indonesia dikancah internasional dengan memperkenalkan potensi keunggulan pariwisata tiap-tiap daerah.

Dengan mengangkat daya tarik wisata halal dengan Lombok Friendly dan Pesona Sumbawa sebagai branding, diharapkan akan mampu meningkatkan kunjungan wisatawan nasional maupun internasional.

Guna mendukung industri pariwisata di Pulau Lombok pemerintah berupa mendukung dengan membangun wadah pendidikan dari SMK sampai Sekolah Tinggi Pariwisata, namun pembangunan industri pariwisata tidak akan berjalan baik tanpa partisipasi dan kesadaran masyarakat guna mendukung program pemerintah, untuk itu pemerintah daerah juga membentuk kelompok Sadar Pariwisata (Pokdarwis) yang diharapkan sebagai kelompok yang akan membangun kesadaran masyarakat sehingga lahirnya produk dan kreatifitas masyarakat. Upaya lain yang dilakukan pemerintah daerah, mengembangkan produk lokal sebagai produk wisata, memberikan akses keungan bagi UMKM serta mendirikan lembaga serifikasi bagi pengusaha lokal.

\section{Implementasi Pariwisata di Pulau Lombok}

Kebijakan untuk mengembangkan pariwisata diharapan mampu memberikan kontribusi peningkatan kesejahteraan masyarakat. Sehingga sejalan dengan tujuan negara mendatangkan kesejahteraan yang berkeadilan.33 Dalam pengembangan pariwisata di pulau lombok terdapat beberapa kendala antara lain, masih rendahnya sumber daya manusia (SDM) baik secara kualitas maupun kuantitas merupakan salah satu penyebab lambatnya perkembangan kepariwisataan di Pulau Lombok. Sumber daya manusia merupakan salah satu komponen vital dalam pembangunan pariwisata. Hampir setiap tahap dan elemen pariwisata memerlukan sumber daya manusia untuk menggerakkannya. Faktor sumber daya manusia sangat menentukan eksistensi pariwisata. Sebagai salah satu industri jasa, sikap dan kemampuan staff akan berdampak krusial terhadap bagaimana pelayanan pariwisata diberikan kepada wisatawan yang secara langsung akan berdampak pada kenyamanan, kepuasan dan kesan atas kegiatan wisata yang dilakukannya. ${ }^{34}$ untuk itu pemerintah daerah provinsi NusaTenggara Barat mulai membangun sekolah tinggi pariwisata serta Sekolah Menengah Keguruan yang tujuannya tidak lain memberikan dukungan dalam pengembangan kegiatan kepariwisataan di pulau lombok dan NTB secara umumnya. Selain hal sumber daya manusia, partisifasi dan sarana prasarana merupakan penujang yang harus yang menjadi perhatian bersama. Selama ini partisifasi masyarakat terhadap penyelenggaraan pariwisata di pulau lombok sangat rendah, menurut L. Hamdan anggota BPPD NTB, rendahnya partisifasi masyarakat dalam bidang pariwisata disebabkan oleh pendidikan masyarakat serta pekerjaan masyarakat yang hampir didominasi oleh petani, buruh sehingga perhatian terhadap pariwisata hanya beberapa komunitas kecil saja. Begitu juga dengan pasilitas penunjang pariwisata yang tidak semua akses menuju destinasi pariwisata tersedia pasilitas yang baik, seperti jalan, penerangan dan keamanan. Hal senada disampaikan oleh Ir.H.Abdul Hakim. MM sekretaris Dinas Pariwisata Lombok Timur beliau memberikan contoh akses jalan menuju beberapa destinasi wisata yang rusak, dan perlu perbaikan dan perhatian baik pemerintah daerah maupun provinsi.

Faktor keamanan juga merupakan faktor penting dalam mendukung kebijakan pemerintah daerah dalam mengembangkan pariwisata, pada tahun 2016 januari- desember, angka kejahatan terhadapat wisatawan meningkat dari 557 kasus menjadi 946 kasus. Didominasi kasus pencurian dan curanmor, 66 kasus terjadi pada wisatawan asing, kekerasan seksual terhadap anak 17, pencabulan 7 kasus, dan 23 kasus kekerasan terhadap anak. ${ }^{35}$ Hal ini tentu akan menjadi kendala besar dalam mendukung pengembangan pariwisata.

\footnotetext{
${ }^{31}$ Wawancara, L. Hamdan, Anggota BPPD NTB tanggal 3 Mei 2017

${ }^{32}$ Wawancara dengan Drs. Alip, Bidang Distinasi Seksi Pengembangan \& Infrastruktur, Dinas Pariwisata dan Kebudayaan Prov.NTB

${ }^{33}$ Elviandri, et.al, The Formulation of welfare state: the perspective of Maqasid, al-Shari'ah,Indonesian Journal of Islam and Muslim Societies, Hlm 118

${ }^{34}$ Pitana dan Diarta, 2009. Pengantar Ilmu Pariwisata, Yogyakarta: Andi, Hlm 72

${ }^{35}$ Suara NTB, Kejahatan Terhadap Wisatwan Asing Naik Signifikan, 4 Januari 2017
} 
Website : http://yustisia.unmermadiun.ac.id/index.php/yustisia

Kebijakan pengembangan pariwisata yang digadang-gadang mampu memberikan kontribusi terhadap peningkatan kesejahteraan masyarakat, dalam kenyataan hanya dinikmati oleh segelintir orang saja (Pengusaha) sementara masyarakat setempat hanya menjadi penonton. Peningkatan pendapatan dan kesejahteraan yang diharapkan ternyata tidak memberi kontribusi besar kepada masyarakat. Justru lahirnya masalah-masalah baru yang diakibatkan dari pengembangan pariwisata. Beberapa akibat dari kebijakan pengembangan pariwisata yang dirasakan oleh masyarakat, Bergeser nilai-nilai kearifan lokal, nilai-nilai kearifan lokal mulai terasa bergeser karena faktor pencampuran budaya yang terjadi, hanya beberapa nilai yang bertahan yang dapat dijadikan sebagai destinasi budaya. Hilangnya dan beralihnya mata pencarian dan pekerjaan masyarakat, kehilangan sumber mata pencarian pun dirasakan dibeberapa komunitas masayarat, misalkan komunitas nelayan pada pantai senggigi yang dilarang memarkirkan nelayan disekitar pantai karena dinilai mengganggu kenyamanan wisatawan. ${ }^{36}$ sehingga hal tersebut mengharuskan para nelayan beralih profesi. Tersingkirnya masyarakat lokal melalui pembebasan lahan, tersingkirnya masyarakat lokal karena lahan yang diperuntukan menjadi ojek wisata terjadi sejak tahun 1984, Sejak lahirnya kebijakan pemerintah Nusa Tenggara Barat dengan diterbitkannya SK Gubernur Nomor 133/1984 Tentang Penunjukan Lokasi dan Pengaturan Penggunaan Tanah Pengembangan Pariwisata di NTB, dan hal ini berlangsung begitu lama sehingga masyarat tidak lagi menjadi tuan pada tanah yang dulu miliknya karena lahan-lahan banyak dikuasai pendatang dan para calo tanah. Kurangnya pemberdayaan masyarakat dalam pengelolaan potensi pariwisata, pariwisata berkenjutan seharusnya memberikan partisipasi masyarakat yang luas, masyarakat diikut sertakan dalam perencanaan, pembangunan dan pengawasan. Namun hal ini belum sepenuh hati dilaksanakan pemerintah daerah.

\section{E. KESIMPULAN}

Arah kebijakan pemerintah daerah khususnya dalam bidang pariwisata di Pulau Lombok yakni pengelolaan pariwisata yang berkelanjutan yang berpegang pada 4 pilar pariwisata, yakni pengembangan destinasi, Pemasaran pariwisatanya, Industri dan Kelembagaannya. Guna mendukung hal tersebut maka pemerintah daerah provinsi mengeluarkan berbagai kebijakan misalkan program visit Sumbawa lombok, Frendly Lombok dan Pesona Sumbawa sebagai branding. Selain hal tersebut diatas pemerintah daerah juga mengembangkan pariwisata halal dengan dikeluarkan peraturan gubernur dan peraturan daerah tentang wisata halal. Kebijakan yang ada saat ini belum banyak memberikan kontribusi kepada peningkatan kesejahteraan masyarakat lombok dan hanya dinikmati manfaat pariwisata ini oleh kelompok tertentu saja (pengusaha) sedangkan pada masyarakat kecil justru melahirkan persoalan baru.

\section{F. DAFTAR PUSTAKA}

Ahmad Nawawi, Partisipasi Masyarakat dalam Pengelolaan Wisata Pantai Depok di Desa Parangtritis, Jurnal Nasional Pariwisata (UGM), Volume 5, Nomor 2, Agustus 2013.

Bungaran Antonius Simanjuntak (at.al),2017, Sejarah Pariwisata, Menuju Perkembangan Pariwisata Indonesia, Buku Obor, Jakarta.

Data Sertifikasi Halal Provinsi Nusa Tenggara Barat,LPPOM MUI NTB, disampaikan dalam Kunjungan kerja Komisi VIII DPR RI.

Destinasi Pariwisata Prioritas Mandalika Dan Sekitarnya, dalam: Laporan Pembangunan Destinasi Pariwisata Prioritas 2016-2019, disampaikan oleh: Dadang Rizki Ratman, SH. MPA. Deputi Bidang Pengembangan Destinasi dan Investasi Pariwisata Kementerian Pariwisata, Disampaikan pada: Rapat Koordinasi Nasional Kementerian Pariwisata "Äkselerasi Pembangunan Kepariwisataan Dalam Rangka Pencapaian Target 12 Juta Wisman dan 260 Juta Wisnus 2016”, Jakarta, 27 Januari 2016.

Edi Suharto, 2008, Kebijakan Sosial Sebagai Kebijakan Publik, Alfabeta, Bandung.

Elviandri, et.al, The Formulation of welfare state: the perspective of Maqasid, al-Shari'ah,Indonesian Journal of Islam and Muslim Societies.

Hessel Nogi S. Tangkilisan,2002, Evaluasi Kebijakan Publik, Penjelasan, Analisis \&Transformasi Pikiran Nagel, Balaiirung \& Co, Yogyakarta.

I Gede Pitana \& Putu G Gayatri, 2005, Sosiologi Pariwisata, Yogyakarta, Andi.

I Gde Pitana \& Ketut Surya Diarta, 2009, Pengantar Ilmu Pariwisata, Yogyakarta, Andi.

Isharyanto, 2016, Hukum Kebijakan Ekonomi Publik, Thafa Media, Yogyakarta.

Iwan Nugroho, Ekowisata dan Pembangunan Berkelanjutan, Pustaka Pelajar, Yogyakarta, 2011.

Junianton Damanik, 2013, Pariwisata Indonesia antara peluang dan Tantangan, Pustaka Pelajar, Jogyakarta.

NTB implementasikan UU JPH, diakses http://www.Republika.co.id , 17 Februari 2017.

Pitana dan Diarta, 2009. Pengantar Ilmu Pariwisata, Yogyakarta: Andi.

Pusat Penelitian dan Pengembangan Usaha Mandiri (P3UM), Survey Referensi Wisatwan Terhadapat Pengembangan Pariwisata, Mataram, Universitas Mataram, 2010.

Regional Liputan6.Com,Bali-Nusra, Hans Bahanan, Dilema Kursi Beton di Senggigi Pilih Nelayan atau Wisatawan, 11 Januari $2018 ; 15.32$ Wib.

Riparda NTB 2015-2019

Riparda, NTB 2013-2028

Samodra Wibawa, 2011, Politik Perumusan Kebijakan Publik, Graha Ilmu, Yogyakarta.

\footnotetext{
${ }^{36}$ Regional Liputan6.Com,Bali-Nusra, Hans Bahanan, Dilema Kursi Beton di Senggigi Pilih Nelayan atau Wisatawan, 11 Januari 2018; 15.32 Wib.
} 
Website : http://yustisia.unmermadiun.ac.id/index.php/yustisia

Suara NTB, Kejahatan Terhadap Wisatwan Asing Naik Signifikan, 4 Januari 2017.

Sukarno Wibisono, Pariwisata sebagai disiplin ilmu yang mandiri, Jurnal Ilmiah Pariwisata.

Soetandyo Wignjosoebroto, Hukum, Paradigma, Metode dan Dinamika Masalahnya, Elsam dan Huma, Jakarta, 2002.

Violetta Simatupang, 2016, Pengaturan Hukum Kepariwisataan Indonesia, Alumni Bandung.

William N Dunn, 2003, Pengantar Analisis Kebijakan Publik, Gadjah Mada Universty. 